

\title{
AN ECONOMETRIC INVESTIGATION INTO THE MACROECONOMIC RELATIONSHIP BETWEEN INVESTMENT AND SAVING:
}

\section{EVIDENCE FROM THE EU REGION}

\section{Constantinos Alexiou*}

\begin{abstract}
By and large, it is beyond any question that sound government finances may indeed be an important factor that conditions economic progress. Nonetheless, the notion that saving must be boosted in order to expand investment, is a contention that has to be taken with a 'pinch of salt'. This study by elaborating on the temporal relationship between investment and saving, provides econometric evidence, on the basis of which investment is a variable with the utmost importance.
\end{abstract}

Key words: Investment, Saving, EU.

JEL: E12, E20

*Contact address: e-mail: alexiou@krasi.demon.co.uk. This paper was written while the author was an academic visitor in the Department of Economics, Queen Mary, University of London, London E1 4NS, England. 


\section{Introduction.}

In the EU region, the prevalence of the neoliberal consensus, as reflected by both the Maastricht criteria and the stability pact, has been the subject of intense debate within the academic community. The emerging policy orientation of pursuing balanced or in surplus budgets as means of revitalising investment has dominated EU's economic policy.

In this study an investigation into the temporal relationship between investment and saving will be conducted. The organisation of this paper is as follows: section 2, using econometric analysis, challenges the widely held neoliberal view that public deficits absorb national saving, raise interest rates, which in turn crowds out investment. In this context, an econometric investigation sheds some light on the underlying macroeconomic relationship between investment and saving. Section 3 provides some conclusions.

\section{Focusing on the Macroeconomic Relationship Between Investment and Saving.}

\subsection{Looking into their temporal relationship.}

Arguably, one of the fundamental reasons why current macroeconomic policy in the EU has shifted towards the elimination of budget deficits, is the emerging neoliberal consensus on how to revitalise investment. Summers and Carroll (1987) emphasise the need to augment private as well as government saving ${ }^{1}$ in order to expand investment. To this effect the proponents of this consensus posit that public and private consumption ${ }^{2}$ must be contained (Hatsopoulos, Krugman, and Summers 1998). In the USA such a belief was rather pervasive in Clinton's vow to cut the federal budget deficit ${ }^{3}$. In Europe the new policy consensus, as implied by both the convergence criteria and the Stability pact, appears to be in line with the tenets of the neoliberal orthodoxy.

Prior to engaging in an econometric investigation, it would be helpful if the national-income accounting identity, that relates savings to investment, is reproduced.

$$
I=S^{P}+S^{G}-N X
$$

where $I$ is investment, $S^{P}$ is private saving $S^{G}$ is net government saving ${ }^{4}$, and $N X$ is net exports. 
Following this identity, investment increases only when either or both private and government savings increase ${ }^{5}$. The, by implication, close relationship between the two variables, identified by a number of economists (see Summers 1988), has provided the platform on which the mainstream ${ }^{6}$ tradition has expounded its theoretical approach.

Arguably, the essence of this national-income accounting identity is purely informative, in that all it tells us is that investment must equal ${ }^{7}$ private and public saving ex post. Therefore, the causal dimension between the two variables given by the mainstream economists may very well be regarded as unfounded ${ }^{8}$. Gordon (1995) argues that 'if investment must equal savings ex post, it could obviously be the case ex ante that investment changes first, and that saving comes subsequently into balance with investment, rather than the other way around' (p.58). The causality in effect - as maintained by both Keynes and Kalecki ${ }^{9}$ - may run from investment to saving rather than vice versa (Harcourt $\&$ Spajic 1998). In the same line of argument, Skott (1989), following the Keynesian ${ }^{10}$ tradition, regards "investment" and income and saving then adapt to bring about the ex-post identity between saving and investment"(p.115).

Assuming that gross saving is composed of undistributed corporate profits, capital consumption allowances, personal saving and government surplus, whereas gross investment is the sum of gross private domestic investment and net foreign investment, how can we be sure that by increasing one component of saving the rest will remain unchanged? For instance, an increase in taxes intended to boost government's saving will cause reductions in both undistributed profits, and disposable income, i.e. reducing personal saving.

The discernible ambiguity between the macroeconomic relationship of those two variables has provided the impetus for conducting some further investigation.

[INSERT TABLE AND FIGURE1]

Table 1, and Fig.1, illustrate the pattern as well as the trend followed by the average of both net investment and net national saving rates, for all European and OECD economies over the period 1961 to 1998 . Following the post-war boom, net investment and net saving 
rates were at rather high levels during the periods 1961 to1966 and 1967 to1972. In the following two periods, the European economies experienced a steady but substantial decline in net investment and net saving rates, whereas in the OECD economies the lowest points were reached during the period 1985-1991. The short-lived sanguine picture observed in Europe during the following period (1985-1991), gave way to a more disappointing spell of lower investment and saving rates over the last time-span.

As regards the OECD economies however, the picture painted over the last period has changed dramatically, in that both net investment and net saving have recovered quite considerably.

\subsection{Net Investment Vs. Net Personal Saving.}

Building on the preceding discussion relating to the relationship between net investment and net saving, an exposition of some additional aspects of the existing relationship will be sought. The proponents of the mainstream ${ }^{12}$ approach would argue that it is the decisions made by private households about personal saving that that the public authorities (the government) have to respond to. In other words, personal saving ${ }^{13}$ is regarded as a major factor responsible for conditioning the relationship between investment and saving. In the analysis to follow, our main concern will be to investigate the relationship between investment and personal savings, since the latter has provided the platform on which the bulk of the current debate has been based.

Our investigation has been confined to what some may call the core EU countries: France, the UK, Belgium Germany and the Netherlands. Throughout, the quantitative analysis annual time series data ${ }^{14}$ ranging from 1972-1998, has been used.

\section{[INSERT TABLE 2]}

Table 2 shows how net investment, personal saving and private saving (all normalised on potential output) behaved over the period 1972 to 1998 . As can be discerned, net investment in the UK, France and the Netherlands peaked during the period 1985-91, whereas in both Germany and Belgium it peaked during the last period. Personal 
savings, in the UK, France, Belgium and the Netherlands reached a peak in the last period whereas in Germany a downward trend is observed throughout all periods. As regards private savings, the pattern exhibited seems to be shared by all five countries, since in all cases it peaks over the last period.

On the basis of the preceding evidence concerning the behaviour of the variables in question, it is interesting to note, that France, the UK, as well as the Netherlands, are characterised by a pattern, according to which, net investment peaks earlier than both personal as well as private saving.

\subsection{Where does the causality run from? Some evidence.}

The pairwise Granger causality test (see Appendix ) is a legitimate way of testing formal hypothesis regarding the relationship between two variables as well as provide inferences about their temporal priority ${ }^{15}$ i.e. which one leads which over time.

The striking feature of the Granger causality tests presented in table 3 below, is the overwhelming rejection of the null hypothesis - that net investment does not Granger cause personal saving -, at the $5 \%$ level of significance, in all five countries ${ }^{16}$ involved in our testing. Technically speaking, information in ascertaining the time-series pattern of personal saving will be lost, unless we take stock of personal saving's covariation with past values of net investment. Conversely, the fact that the null hypothesis that personal saving does not Granger cause net investment can not be rejected at the 5\% significance level in all five cases, suggests that even if we exclude personal saving from the regression no statistical information will be lost.

[INSERT TABLE 3] 
Following the preceding empirical analysis it can be argued that the emerging evidence points towards a macroeconomic relationship according to which investment leads personal saving and therefore the determination of investment precedes the one of personal saving.

\subsection{A Vector Autoregression (VAR) approach.}

As it has become clear from the preceding analysis, descriptive statistics as well as single equations provided the major tools with which we tried to investigate the investmentsaving relationship. Arguably, the determination of both investment and saving involves a string of other factors, that can have a profound impact on both variables, such as the real interest rate ${ }^{17}$, or the profitability ${ }^{18}$. It is necessary, therefore, to take the investigation one step further so that a more lucid picture emerges. To this effect, we develop a VAR ${ }^{19}$ model that consists of four endogenous variables: net investment, net personal saving, a measure of profitability ${ }^{20}$, and interest rates. In our context, we use annual data ${ }^{21}$ for France, the UK, Belgium, Germany and the Netherlands from 1972 to 1998.

Our primary focus while dealing with the VAR approach will be on discussing the decomposition of the variance of the variables in the system, at various horizons. By subjecting all endogenous variables in the VAR model to standard deviation shocks we can obtain information about the relative significance of each random innovation to the variable in the VAR. In other worlds, for each period the resulting simulated error, in each endogenous variable, is decomposed into the error due to its own innovations, and the error $^{22}$ due to innovations in the endogenous variables. The significance of this task rests in the magnitude of the percentage of the variance of each endogenous variable. High percentage of variance over a long period implies that the variable is largely exogenous to the system. In contrast, a high percentages of variance that declines fairly quickly with time, implies that the variable is significantly conditioned by the variables in the system ${ }^{23}$.

\section{[INSERT TABLE 4]}


Table 4 provides a summary of the variance decomposition of both saving and investment, conditioned by the rest of the endogenous variables, for periods from one to five lags. An inspection of the columns corresponding to the UK, reveals the following: The portion of saving's variance due to its own innovations after reaching 100 percent in the first period, has declined considerably over the next periods, down to only 18.4 percent after five periods, whereas the portion of variance, due to investment has remained relatively high over all five periods, before it gives way to the rest of the variables in the system. Conversely, the portion of investment's variance due to its own innovations displays a smoother pattern, remaining relatively high throughout all periods. Further more, the portion of its variance due to saving, rises to 23.8 per cent before it declines again. The above evidence suggests that the relative contribution of investment's innovation to saving's variance is much greater than the relative contribution of the saving's innovation to investment' variance through out the entire period.

In France, unlike the UK, the portion of saving's variance due to its own innovation has remained relatively high over all five periods, whereas the portion due to investment, after a sluggish start, has only risen to 12.1 per cent. The story concerning the portion of investment's variance due to its own as well as saving's innovations appears to be unfolding in a rather similar fashion. The only difference is that, this time, the portion of investment's variance due to saving exhibits a more stable pattern before it reaches 15.7 per cent. The emerging evidence indicates that the relative contribution of saving's innovation to investment's variance dominates, not by much, the relative contribution of investment's innovation to saving's variance.

In Belgium, the picture appears to be rather ambiguous. Over the first two periods, the contribution of saving's innovation to investment's variance is distinctly greater than the contribution of investment's innovation to saving' variance. In the remaining three periods however, the story changes with investment dominating saving.

As regards Germany, the evidence obtained points to a more balanced picture since both the contribution of saving's innovation to investment's variance, as well as the contribution of investment's innovation to saving's variance, are of the same magnitude. 
Finally, in Netherlands' case, the portion of savings due to its own innovation has remained quite high during all periods, whereas the portion of savings due to innovation in investment has not exceeded the 6 per cent mark. Furthermore, the portion of investment due to innovation in savings has remained rather low, whereas the portion of investment due to its own innovation, despite the high percentages in the first two periods, has declined substantially over the last three periods. Such a development can be put down to the influence ( 72 per cent in the last period) of the remaining variables - the profit share, and interest rate - on the portion of investment.

On the basis of the evidence obtained serious doubts are cast on the existing relationship between investment and saving. In particular, it could be argued that the macroeconomic relationship between personal saving and investment has to be carefully reinvestigated.

\section{Concluding remarks.}

The impetus for investigating this relationship was given by the prevailing policy consensus, in the so-called developed capitalistic countries, that large budget deficits absorb national saving, and therefore impede investment, in which case, consumption has to be curbed and budget deficits have to be eliminated. Our effort sought to establish the way the causality between net personal saving and net investment runs.

The empirical investigation that was carried out for six EU countries cast considerable doubt upon the notion that increases in saving will boost investment. The Granger causality test pointed to a relationship, on the basis of which, investment leads saving. In pursuing a deeper understanding of the existing relationship a four-variable VAR model was set up for each country individually. By decomposing the variance of each variable, the results backed the view of those who regard investment as being a potential variable of the utmost importance. 
Table 1. Net Investment and Net National Saving rates for EU-15 and OECD economies.

\begin{tabular}{ccccc}
\hline $\begin{array}{c}\text { Time } \\
\text { Periods }\end{array}$ & $\begin{array}{c}\text { Net Investment } \\
\text { as \% of GDP } \\
\text { EU }\end{array}$ & $\begin{array}{c}\text { N. N. Saving as } \\
\text { \% of GDP } \\
\text { EU }\end{array}$ & $\begin{array}{c}\text { Net Investment } \\
\text { as of GDP } \\
\text { OECD }\end{array}$ & $\begin{array}{c}\text { N. N. Saving as } \\
\text { of GDP } \\
\text { OECD }\end{array}$ \\
\hline $1961-1966$ & 8.3 & 7.2 & 10.2 & 9.3 \\
\hline $1967-1972$ & 8.9 & 9.8 & 9.8 & 10.6 \\
\hline $1973-1978$ & 7.2 & 6.9 & 10.4 & 9.6 \\
\hline $1979-1984$ & 4.6 & 4.1 & 5.4 & 4.9 \\
\hline $1985-1991$ & 10.8 & 9.0 & 6.1 & 5.8 \\
\hline $1992-1998$ & 7.0 & 6.0 & 17.6 & 17.2 \\
\hline
\end{tabular}

Source: OECD.

Fig. 1.

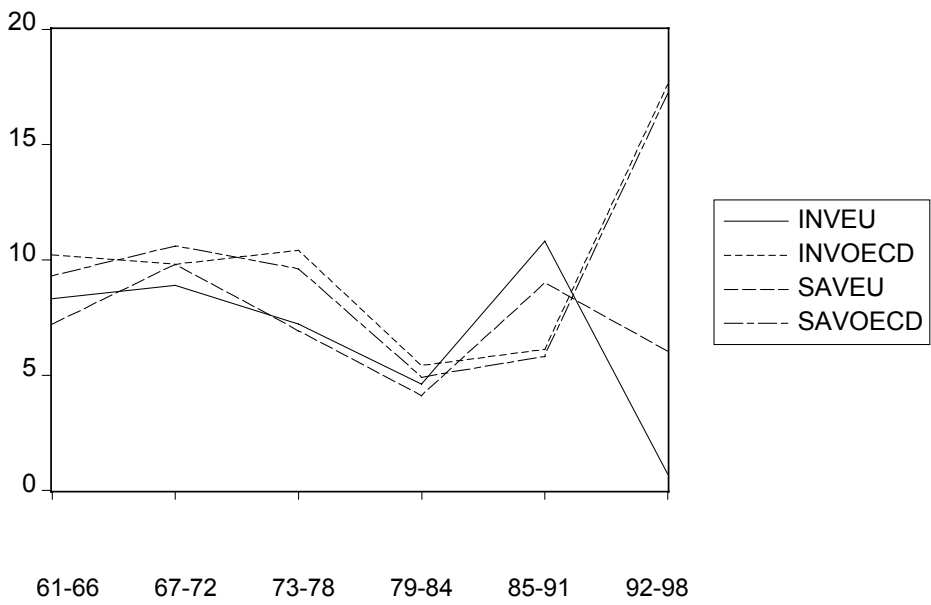


Table 2. Net investment and personal savings for France, UK, and Belgium (averages).

\begin{tabular}{|c|c|c|c|c|}
\hline Country & Periods & $\begin{array}{l}\text { Net investment } \\
\text { (\% of potential } \\
\text { output) }\end{array}$ & $\begin{array}{l}\text { Net personal } \\
\text { saving }^{24} \\
\text { (\% of potential } \\
\text { output })\end{array}$ & $\begin{array}{c}\text { Net private } \\
\text { saving }{ }^{25} \\
\text { (\% of potential } \\
\text { output) }\end{array}$ \\
\hline \multirow[t]{4}{*}{ France } & $1972-1978$ & 19.2 & 7.3 & 18.0 \\
\hline & $1979-1984$ & 15.4 & 7.2 & 16.8 \\
\hline & $1985-1991$ & 16.2 & 2.6 & 15.5 \\
\hline & $1992-1998$ & 11.7 & 4.9 & 17.7 \\
\hline \multirow[t]{4}{*}{$U K$} & $1972-1978$ & 12.1 & 2.6 & 14.0 \\
\hline & $1979-1984$ & 11.9 & 2.5 & 17.1 \\
\hline & $1985-1991$ & 13.3 & 1.6 & 12.6 \\
\hline & $1992-1998$ & 10.2 & 3.4 & 15.1 \\
\hline \multirow[t]{4}{*}{ Belgium } & $1972-1978$ & 18.6 & 8.1 & 19.4 \\
\hline & $1979-1984$ & 15.2 & 9.1 & 17.4 \\
\hline & $1985-1991$ & 13.0 & 7.2 & 19.7 \\
\hline & $1992-1998$ & 13.5 & 7.7 & 20.5 \\
\hline \multirow[t]{4}{*}{ Germany } & $1972-1978$ & 19.4 & 6.5 & $\mathrm{n} / \mathrm{a}$ \\
\hline & $1979-1984$ & 14.0 & 6.3 & 21.2 \\
\hline & $1985-1991$ & 13.2 & 6.1 & 22.1 \\
\hline & $1992-1998$ & 14.7 & 5.3 & 22.7 \\
\hline \multirow[t]{4}{*}{ Netherlands } & $1972-1978$ & 23.3 & 7.1 & $\mathrm{n} / \mathrm{a}$ \\
\hline & $1979-1984$ & 15.8 & 7.3 & $\mathrm{n} / \mathrm{a}$ \\
\hline & $1985-1991$ & 16.6 & 2.6 & 26.2 \\
\hline & $1992-1998$ & 14.3 & 4.9 & 26.8 \\
\hline
\end{tabular}

Source: European Economy. 
Table 3. Pairwise Granger causality test on the temporal relationship between net investment and personal saving as well as between net investment and private saving.

\begin{tabular}{|c|c|c|}
\hline Country & $\begin{array}{c}\text { Null hypothesis: } \\
\text { Personal saving /[ private } \\
\text { saving] does not Granger } \\
\text { cause net investment }\end{array}$ & $\begin{array}{l}\text { Null hypothesis: } \\
\text { Net investment does not } \\
\text { Granger cause personal } \\
\text { saving /[ private saving] }\end{array}$ \\
\hline \multirow[t]{2}{*}{ France } & $1.85(0.18)_{2} /[\mathrm{N}]$ & $3.00(0.05)_{2} * /[4.51(0.03)]^{*}$ \\
\hline & $0.18(0.67)_{3} /[\mathrm{N}]$ & $3.11(0.06)_{3} * /[4.30(0.04)]^{*}$ \\
\hline \multirow[t]{2}{*}{$U K$} & $1.93(0.17)_{2} /[\mathrm{N}]$ & $3.76(0.04)_{2} * /[3.82(0.02)]^{*}$ \\
\hline & $0.92(0.44)_{3} /[\mathrm{N}]$ & $3.80(0.02)_{3} * /[3.53(0.04)]^{*}$ \\
\hline \multirow[t]{2}{*}{ Belgium } & $0.34(0.56)_{2} /[\mathrm{N}]$ & $7.44(0.01)_{2} * /[6.30(0.01)]^{*}$ \\
\hline & $0.42(0.65)_{3} /[\mathrm{N}]$ & $4.24(0.02)_{3} * /[5.23(0.03)]^{*}$ \\
\hline \multirow[t]{2}{*}{ Germany } & $2.64(0.10)_{2} /[\mathrm{N}]$ & $9.80(0.00)_{2} * /[8.30(0.00)]^{*}$ \\
\hline & $1.20(0.34)_{3} /[\mathrm{N}]$ & $5.45(0.01)_{3} * /[7.56(0.00)] *$ \\
\hline \multirow[t]{2}{*}{ Netherlands } & $2.31(0.15)_{2} /[\mathrm{N}]$ & $3.56(0.04)_{2} * /[3.43(0.04)]^{*}$ \\
\hline & $1.63(0.23)_{3} /[\mathrm{N}]$ & $2.87(0.06)_{3} * /[2.94(0.06)]^{*}$ \\
\hline
\end{tabular}

Note: The test was conducted at the $5 \%$ level of significance. Probabilities are given in parentheses. Subscripts denote number of $\operatorname{lags}^{26}$ included in test, whereas an ${ }^{*}$ denotes significant test. 
Table 4. Variance decomposition of responses to innovations in a four-variable VAR system. \%

\begin{tabular}{|c|c|c|c|c|c|c|}
\hline$U \boldsymbol{U K}$ & \multicolumn{3}{|c|}{ \% Variance Decomposition Sav. } & \multicolumn{3}{|c|}{ \% Variance decomposition Inv. } \\
\hline Periods & Sav. & Inv. & Others & Sav. & Inv. & Others \\
\hline 1 & 100.0 & 0.0 & 0.0 & 0.5 & 99.5 & 0.0 \\
\hline 2 & 34.9 & 50.2 & 14.9 & 20.9 & 78.2 & 0.9 \\
\hline 3 & 24.9 & 47.4 & 27.7 & 23.8 & 63.5 & 12.7 \\
\hline 4 & 21.9 & 51.6 & 26.5 & 19.9 & 53.0 & 27.1 \\
\hline 5 & 18.4 & 50.1 & 31.5 & 19.3 & 48.8 & 31.9 \\
\hline France & \multicolumn{3}{|c|}{ \% Variance Decomposition Sav. } & \multicolumn{3}{|c|}{ \% Variance decomposition Inv. } \\
\hline Periods & Sav. & Inv. & Others & Sav. & Inv. & Others \\
\hline 1 & 100.0 & 0.0 & 0.0 & 7.3 & 92.6 & 0.1 \\
\hline 2 & 94.7 & 5.0 & 0.3 & 12.5 & 85.7 & 1.8 \\
\hline 3 & 93.1 & 6.0 & 0.9 & 12.7 & 84.7 & 2.6 \\
\hline 4 & 82.9 & 7.1 & 10.0 & 10.7 & 86.3 & 3.0 \\
\hline 5 & 78.8 & 12.1 & 9.1 & 15.7 & 80.6 & 3.7 \\
\hline Belgium & \multicolumn{3}{|c|}{ \% Variance Decomposition Sav. } & \multicolumn{3}{|c|}{ \% Variance decomposition Inv. } \\
\hline Periods & Sav. & Inv. & Others & Sav. & Inv. & Others \\
\hline 1 & 100.0 & 0.0 & 0.0 & 4.3 & 95.7 & 0.0 \\
\hline 2 & 98.4 & 0.1 & 1.5 & 4.4 & 83.0 & 12.6 \\
\hline 3 & 94.1 & 3.7 & 2.2 & 3.6 & 81.8 & 14.6 \\
\hline 4 & 84.2 & 9.7 & 6.1 & 3.5 & 77.8 & 18.7 \\
\hline 5 & 76.0 & 16.8 & 7.2 & 3.7 & 65.4 & 30.9 \\
\hline Germany & \multicolumn{3}{|c|}{ \% Variance Decomposition Sav. } & \multicolumn{3}{|c|}{ \% Variance decomposition Inv. } \\
\hline Periods & Sav. & Inv. & Others & Sav. & Inv. & Others \\
\hline 1 & 100.0 & 0.0 & 0.0 & 5.4 & 94.6 & 0.0 \\
\hline 2 & 89.5 & 8.6 & 1.9 & 3.5 & 94.5 & 2.0 \\
\hline 3 & 85.5 & 12.0 & 2.5 & 6.8 & 88.8 & 4.4 \\
\hline 4 & 81.4 & 14.0 & 4.6 & 11.5 & 82.4 & 6.1 \\
\hline 5 & 78.8 & 14.0 & 7.2 & 15.5 & 76.7 & 7.8 \\
\hline Netherla. & \multicolumn{3}{|c|}{ \% Variance Decomposition Sav. } & \multicolumn{3}{|c|}{ \% Variance decomposition Inv. } \\
\hline Periods & Sav. & Inv. & Others & Sav. & Inv. & Others \\
\hline 1 & 100.0 & 0.0 & 0.0 & 3.3 & 96.7 & 0.0 \\
\hline 2 & 83.8 & 8.1 & 8.1 & 6.4 & 71.0 & 22.6 \\
\hline 3 & 74.1 & 8.8 & 17.1 & 3.6 & 40.0 & 56.4 \\
\hline 4 & 73.3 & 7.0 & 19.7 & 4.2 & 26.0 & 69.8 \\
\hline 5 & 75.4 & 6.0 & 18.6 & 7.9 & 20.0 & 72.1 \\
\hline
\end{tabular}

Notes: Due to limited space we have added up the rest of the variables which, in this case, is reflected by 'others'. 


\section{APPENDIX}

According to the Granger (1969) approach, the question of whether $x$ causes $y$, is to see how much of the current $y$ can be explained by past values of $y$ and then to see whether adding lagged values of $x$ can improve the explanation. $Y$ is said to be Granger-caused by $x$ if it helps in the prediction of $y$, or equivalently if the coefficients on the lagged $x$ 's are statistically significant. It is important to note that the statement "x Granger causes $y$ " does not imply that $y$ is the effect or the result of $x$. Granger causality measures precedence and information content but does not by itself indicate causality in the more common use of them.

The test is carried out by running bivariate regressions of the form

$$
\begin{aligned}
& y_{t}=\alpha_{0}+\alpha_{1} y_{t-1}+\cdots \cdots+\alpha_{l} y_{t-l}+\beta_{1} x_{t-1}+\cdots \cdots+\beta_{l} x_{t-l} \\
& x_{t}=\alpha_{0}+\alpha_{1} x_{t-1}+\cdots \cdots+\alpha_{l} x_{t-l}+\beta_{1} y_{t-1}+\cdots \cdots+\beta_{l} y_{t-l}
\end{aligned}
$$

for all possible pairs of $(x, y)$ series in the group. The reported F-statistics are the Wald statistics for the joint hypothesis

$$
\beta_{1}=\cdots \cdot=\beta_{l}=0
$$

for each equation. The null hypothesis is therefore that $x$ does not Granger-cause $y$ in the first regression and that $y$ does not Granger-cause $x$ in the second regression. 


\section{Endnotes:}

1 ".....neoclassical growth models have, again with little irony, cast a dark cloud on the effectiveness of saving as a positive force on the rate of economic growth" (Hamberg, 1971: pp.141-2).

${ }^{2}$ Eisner (1995) maintains that such an antiquated reasoning is totally absurd.

${ }^{3}$ In a rather characteristic manner, President Clinton attributed the low growth rate in domestic investment to the crippling large budget deficits.

${ }^{4}$ This is equal to government revenue minus government spending (government surplus).

${ }^{5}$ Such a contention is predicated on the condition that net exports does not affect the determination of the investment-savings equilibrium.

${ }^{6}$ The view that by changing one component of saving, we can achieve major changes in the components on investment, might be the case, provided that we assume all other things constant (Eisner 1995).

${ }^{7}$ Asimakopoulos (1983) posits that neither Keynes nor Kalecki envisaged the time required that takes for the multiplier effects of a higher level of investment to be worked out. $\mathrm{He}$ goes on to argue that "Keynes even appeared at times to confuse the definitional equality between saving and investment with the equilibrium relation between them"(p.222).

8 'Keynes' intellectual revolution was to shift economists from thinking normally in terms of a model of reality in which a dog called savings wagged his tail labeled investment to thinking in terms of a model in which a dog called investment wags his tail called saving'. Meade (1975; p.62)

${ }^{9}$ They both looked upon investment as the causal determinant of saving in the short-term, since it affects the level of output (Keynesian view) as well as the distribution of income (Kalecki's view).

${ }^{10}$ Keynes (1964) regarded saving as a passive 'determinant' of the system (p.183).

${ }^{11}$ Both Keynes and Kalecki regarded investment as the key determinant of the level of economic activity. According to Kalecki (1971: p.13) "...capitalists, as a whole, determine their own profits by the extent of their investment and personal consumption. In a way they are 'masters of their fate'; but how they 'master' it is determined by objective factors, so that fluctuations of profits appear after all to be unavoidable". In the same spirit, Keynes' (1973: p.121) argued that the "level of output and employment as a whole depends on the amount of investment. I put it this way, not because this is the only factor on which aggregate output depends, but because it is usual in a complex system to regard as the causa causans that factor which is most prone to sudden and wide fluctuation. More comprehensively, aggregate output depends on the propensity to hoard, on the policy of the monetary authority as it affects the quantity of money, on the state of confidence concerning the prospective yield of capital assets, on the propensity to spend and on the social factors which influence the level of money wage. But of these several factors it is those which determine the rate of investment which are most unreliable, since it is they which are influenced by our views of the future about which we know so little." Asimakipoulos (1983) points out that for both Keynes and Kalecki banks liquidity determines the rate of investment. "For both it was the subsequent changes in income (as 
well as the distribution of income for Kalecki) that brought desired saving into equality with the increase in investment."(p.233).

12 According to the neoclassical approach the main determinants of investment decisions are: the aggregate income, and the interest rate. On the other hand, personal saving decisions, according to the life cycle - permanent income hypothesis of consumption, are believed to depend on fluctuations in income, the interest rate and wealth.

${ }^{13}$ It should be stressed that within the neoclassical tradition total private saving is also being given some consideration. Arguably, households optimize total private saving.

${ }^{14}$ We normalized our data by dividing by potential output in order to control for increases in the scale of the economy.

${ }^{15}$ This becomes feasible, by regressing $\mathrm{X}$ on its own values as well as lags of $\mathrm{Y}$ and then reversing the test with $\mathrm{Y}$ this time your dependent variable.

${ }^{16}$ It should be noted, however, that in the Netherlands the Granger causality test involving two lags is found to be insignificant either way.

${ }^{17}$ The proponents of the neoclassical approach would argue that the real interest rate should be included in an equation involving the two variables in question.

${ }^{18}$ According to those sharing the Keynesian, Kaleckian, as well as Marxian perspective, profitability can have a profound impact on both investing and saving decisions. It should be pointed out that the proponents of the neoclassical theory regard the before-tax profit rate or profit share as a variable of no analytical significance, and therefore ignore its impact on net national saving ( Desai, 1987).

${ }^{19}$ For more on VAR models see Sims (1980), Campbell (1991).

${ }^{20}$ The profit share, which has been used as a measure of profitability, attempts to capture the effects of distribution as well as the cost of capital services on investment. (Gordon 1995). In addition, the three-month treasury bill rate was used as a proxy for interest rates since according to the neoclassical theory serves as means of equilibrating saving and investment.

${ }^{21}$ OECD, European Economy, as well as the Datastream were the main providers of our data.

${ }^{22}$ The sum of the variances of all endogenous variables must add up to 100 .

${ }^{23}$ We should emphasize that the order according to which all variables have been included in the VAR system is of great importance. For the first variable the only one period ahead variation is its own innovation; hence the high percentage (100\%). In our experiment saving has been chosen as the first variable.

${ }^{24}$ By net personal savings we refer to net savings of households.

${ }^{25}$ Private savings is the sum of personal and private sector savings.

${ }^{26}$ It should be emphasised that our intention is to focus on long-term effects between investment and saving. Hence, the lags employed in our analysis. 


\section{References}

Asimakopoulos, A. (1983) "Kalecki and Keynes on Finance, Investment and Saving", Cambridge Journal of Economics, 7, pp.221-233.

Campbell, J. (1991) “A Variance Decomposition of Stock Returns”, Economic Journal, 101, pp.157-179.

Cesaratto, S. (1999) "Savings and Economic Growth in Neoclassical Theory", Cambridge Journal of Economics, 23, pp.771-793.

Desai, M. (1987) "Profit and Profit Theory", in J. Eatwell et al. (eds.), The New Palgrave Dictionary of Economics, Vol. III, London: Macmillan, pp.1014-21.

Eisner, R. (1995) "US National Saving and Budget Deficits", in Epstein, A. G. \& Gintis, M. H. (1995) Macroeconomic Policy After the Conservative Era, Cambridge University Press.

Eisner, R. (1995) "Our NAIRU Limits: The Governing Myth of Economic Policy", The American Prospect, Spring 1995, pp. 58-63.

Gordon, D. (1995) "Putting the Horse (back) before the Cart: Disentangling the Macro Relationship between Investment and Saving", in Epstein, A. G. \& Gintis, M. H. (eds.) Macroeconomic Policy After the Conservative Era, Cambridge University Press.

Granger, C. W. J. (1969) "Investigating Causal Relations by Econometric Models and Cross Spectral Methods", Econometrica, pp.424-38.

Hamberg, D. (1971) "Models of Economc Growth", New York, Harper \& Row.

Harcourt, G. C. et al. (1998) "Post-Keynesianism”, Working Paper, Cambridge.

Hatsopoulos, G., et al. (1998) "US Competitiveness: Beyond the Trade Deficit", Science, 241, July 15, pp.299-307.

Kalecki, M. (1971) "Selected Essays and the Dynamics of the Capitalist Economy", Cambridge: Cambridge University Press.

Keynes, J. M. (1964) "The General Theory of Employment, Interest, and Money", New York: Harcourt, Brace and World.

Keynes, J. M. (1973a) "The General Theory of Employment, Interest, and Money", in The Collected Writings of John Maynard Keynes, Vol. VII, London Macmillan.

Meade, J. (1975) "The Keynesian Revolution", in Keynes, M (eds.) Essays on John Maynard Keynes.

Sims, A. (1980) "Macroeconomics and Reality", Econometrica, January, 48(1): 1-48.

Skott, P. (1989) "Conflict and Effective Demand in Economic Growth", Cambridge University Press.

Summers, L. (1988) " Tax Policy and International Competitiveness", in J. Frankel (eds.) International Aspects of Fiscal Policies, Chicago: University of Chicago Press, pp.349-375. Summers, L. \& C. Carroll, (1987) "Why is US National Saving so Low?", Brooking Papers on Economic Activity, 2, pp.607-635. 


\section{Q Queen Mary \\ University of London}

This working paper has been produced by the Department of Economics at Queen Mary, University of London

Copyright ( 2002 Constantinos Alexiou All rights reserved.

\section{Department of Economics}

Queen Mary, University of London

Mile End Road

London E1 4NS

Tel: +44 (0)20 78825096 or Fax: +44 (0)20 89833580

Email: j.conner@qmul.ac.uk

Website: www.econ.qmul.ac.uk/papers/wp.htm 